\title{
Identifikasi Morfometrik Sperma Domba Lokal sebagai Dasar Aplikasi Sexing Sperma
}

\author{
N. Solihati ${ }^{1 a}$, S. D. Rasad $^{1}$, A. Yusrina ${ }^{1}$, Y. I. Dimyati ${ }^{1}$ \\ ${ }^{I}$ Fakultas Peternakan Universitas Padjadjaran Bandung \\ aemail:nurcholidah@unpad.ac.id
}

\begin{abstract}
Abstrak
Penelitian ini bertujuan untuk mengidentifikasi ukuran-ukuran sperma berdasarkan metode morfometrik sebagai dasar untuk_aplikasi sexing sperma pada Domba Lokal. Penelitian ini dilakukan dengan menggunakan 20 ekor Domba Lokal umur lebih dari satu tahun, yang ditampung semennya dan dibuat preparat differensial. Pengamatan morfometrik sperma dilakukan di bawah mikroskop cahaya pembesaran 10x100 menggunakan aplikasi DP2BSW. Parameter yang diamati meliputi ukuran panjang, lebar dan luas kepala sperma serta panjang ekor sperma. Pengukuran dilakukan terhadap 70 sd 200 sel sperma untuk setiap parameter. Data yang diperoleh dihitung nilai minimum, maksimum dan standar deviasi dari setiap parameter. Hasil penelitian menunjukkan bahwa kepala sperma memiliki rataan panjang minimum $6,85 \pm 0,40 \mu \mathrm{m}$ dan maksimum $10,27 \pm 0,51 \mu \mathrm{m}$; rataan lebar kepala sperma minimum $3,76 \pm 0,43 \mu \mathrm{m}$ dan maksimum $6,71 \pm 0,43 \mu \mathrm{m}$; rataan luas kepala sperma

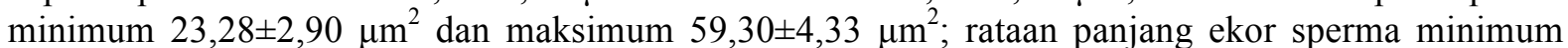
$36,74 \pm 6,73 \mu \mathrm{m}$ dan maksimum $69,53 \pm 3,42 \mu \mathrm{m}$. Berdasarkan hasil-hasil penelitian tersebut, diketahui bahwa sperma Domba Lokal memiliki ukuran minimum dan maksimum yang selanjutnya dapat diidentifikasi sperma pembawa kromosom X dan Y serta proporsinya. Disimpulkan bahwa hasil morfometrik sperma Domba Lokal dapat digunakan sebagai dasar untuk sexing sperma pada Domba Lokal.
\end{abstract}

Kata kunci: panjang, lebar, luas kepala sperma, panjang ekor

\section{Morfometric Identification of Local Ram Sperm for Sexing Sperm Aplication}

\begin{abstract}
This research aim to identified the sizes of sperm base on morfometric methode as basic for aplication of sperm sexing on Local Ram. This research was done by deskriptip methode used 20 Local Ram that was collected their semen and were made the differential preparate. Evaluation of sperm morfometric was done using light microscope with magnification $10 \times 40$ used DP2BSW aplication. Parameters were observed consist of length, width, wide of sperm head, and tail length. Evaluation was done for about 70 until 200 sperm cells for each parameters. Data collection base on the minimun, maksimum and standar deviation value off each paramater. The result showed that the

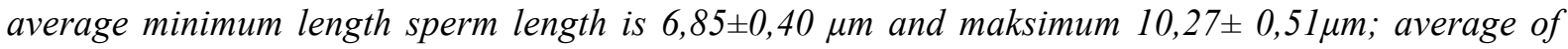

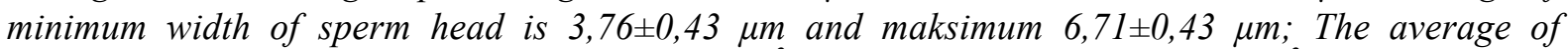

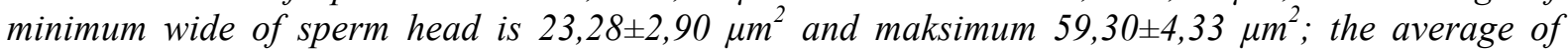
minimum of tail length $36,74 \pm 6,73 \mu \mathrm{m}$ and maksimum $69,53 \pm 3,42 \mu \mathrm{m}$. Base on this result, Local Rams sperm have minimum and maksimum sizes and then could be identified as Xand Y chromosome bearing sperm and its proportion. It is concluded that morphometric result of Local Ramsperm could be used base for sperm sexing on Local Ram.
\end{abstract}

Key words: length, width, sperm head wide, tail long

\section{Pendahuluan}

Aplikasi teknologi reproduksi merupakan salah satu pendekatan untuk meningkatkan populasi ternak khususnya Domba Lokal. Penelitian mengenai performa reproduksi Domba Lokal telah dilaporkan sebelumnya diantaranya yang berkaitan dengan kualitas semen Domba Lokal umur pubertas (Solihati et al, 2015), umur Domba Lokal yang menghasilkan kualitas semen terbaik (Solihati et al., 2016a), penggunaan krioprotektan untuk semen beku Domba Lokal (Solihati

et $a l$, 
2016b; Solihati et al, 2016c). Peningkatan populasi Domba Lokal dibutuhkan berkaitan dengan penyediaan daging sebagai sumber percepatan peningkatan populasi Domba Lokal jantan yang dapat diupayakan melalui aplikasi teknologi reproduksi melalui metode sexing sperma.

Metode sexing sperma dapat dilakukan dengan beberapa cara, salah satunya dengan metode kolum albumin. Prinsip dari media ini adalah adanya perbedaan kecepatan motilitas antara spermatozoa $\mathrm{X}$ dan $\mathrm{Y}$ serta perbedaan konsentrasi pada media separasi. Spermatozoa Y memiliki motilitas lebih tinggi dibanding dengan $X$. Adanya perbedaan konsentrasi pada media albumin yang digunakan menyebabkan spermatozoa dengan motilitas tinggi diperkirakan akan mampu menembus lapisan media konsentrasi yang lebih tinggi sedangkan spermatozoa yang motilitasnya rendah akan tertinggal pada media dengan konsentrasi rendah. Dengan demikian pada lapisan bawah dengan konsentrasi lebih tinggiakan ditemukan mayoritas spermatozoa Y, sedangkan pada lapisan atas dengan konsentrasi lebih rendah akan diperoleh spermatozoa $X$. Penentuan spermatozoa $X$ dan $Y$ secara morfometrik yaitu berdasarkan temuan bahwa spermatozoa $\mathrm{X}$ memiliki ukuran lebih besar dibanding spermatozoa Y. Berdasarkan prinsip kerja metode tersebut maka perlu diketahui informasi dasar mengenai ukuran-ukuran sperma pada Domba Lokal sebagai dasar aplikasi sexing sperma dengan metode kolom albumin. Berdasarkan ukuran-ukuran sperma dapat diidentifikasi sperma $\mathrm{X}$ dan sperma $\mathrm{Y}$ sehingga dapat diketahui proporsi kedua jenis sperma tersebut. Penelitian sebelumnya telah dilaporkan bahwa proporsi alamiah antara sperma pembawa kromosom X dan Y pada Domba Lokal yaitu 50,70\% X : 49,30\% Y (Solihati et al., 2017).

\section{Materi dan Metode}

Materi penelitian berupa semen yang berasal dari 20 ekor pejantan Domba Lokal umur lebih dari satu tahun. Penelitian dilakukan di Laboratorium Reproduksi Ternak dan Inseminasi Buatan pada bulan April sampai Mei 2017. Koleksi semen dilakukan dengan metode vagina buatan untuk selanjutnya dibawa ke laboratorium untuk dibuat preparat differensial untuk pengukuran panjang, lebar, luas kepala sperma dan panjang protein hewani. Berkaitan dengan hal tersebut diperlukan

ekor sperma. Setiap ekor Domba Lokal dibuat satu preparat, setiap preparat dihitung minimal 70 sel sperma. Pengukuran panjang dan lebarsperma dilakukan terhadap sperma yang memiliki bentuk utuh dan tidak bertumpul dengan sperma yang lain pada setiap preparat yang diamati, sehingga jumlah sperma yang diukur pada setiap preparat memiliki jumlah yang tidak sama yaitu berkisar antara 70 sampai 200 sel sperma.

Pengukuran ukuran-ukuran sperma dilakukan dengan menggunakan aplikasi DP2BSW dengan pembesaran 10x100. Luas kepala sperma dihitung melalui metode integral Riemann (Purcell and Varberg, 1987) dan metode analisis regresi (Steel and Torie 1995) untuk menguji hubungan antara panjang dan lebar kepala sperma.

$\begin{array}{lll}\text { Keterangan } & : & \\ \text { LKS } & : \text { Luas Kepala Spermatozoa } \\ 0,8988 & : & \text { faktor koreksi yang } \\ \text { dibangkitkan } & \text { dari data yang ada dengan } \\ \text { menerapkan } & & \\ & \text { metode integral untuk } \\ & \text { menentukan luas kepala } \\ & \text { spermatozoa dari setiap satuan } \\ & \text { ukuran dan metode regresi } \\ & \text { untuk menentukan hubungan } \\ & \text { ukuran panjang dan lebar } \\ & \text { dengan luas } \\ & \text { spermatozoa kepala } \\ \text { P } & \text { Panjang kepala spermatozoa } \\ \text { L } & \text { Lebar kepala spermatozoa } \\ 1,63 & \text { Nilai konstanta regresi }\end{array}$

\section{Hasil dan Pembahasan}

Hasil pengukuran morfometrik terhadap 20 ekor sperma Domba Lokal tercantum pada Tabel 1. Hasil penelitian menunjukkan bahwa kepala sperma memiliki rataan panjang minimum $6,85 \pm 0,40 \mu \mathrm{m}$ dan maksimum $10,27 \pm 0,51 \mu \mathrm{m}$; rataan lebar kepala sperma minimum $3,76 \pm 0,43 \mu \mathrm{m}$ dan maksimum $6,71 \pm 0,43 \mu \mathrm{m}$; rataan luas kepala sperma minimum $23,28 \pm 2,90 \mu \mathrm{m}^{2}$ dan maksimum $59,30 \pm 4,33 \mu \mathrm{m}^{2}$; rataan panjang ekor sperma minimum $36,74 \pm 6,73 \mu \mathrm{m}$ dan maksimum $69,53 \pm 3,42 \mu \mathrm{m}$. Berdasarkan data yang diperoleh dapat dilihat bahwa standar 
deviasi dari ukuran panjang, lebar dan luas kepala sperma menunjukkan nilai yang rendah yang berarti bahwa kisaran nilai ukuranukuran tersebut tidak berbeda jauh. Namun pada nilai minimum panjang ekor, standar deviasi cukup tinggi yang menunjukkan bahwa ukuran minimum panjang ekor memiliki kisaran yang cukup luas.

Berdasarkan data yang diperoleh dapat dilihat bahwa tidak terdapat hubungan linear antara luas kepala sperma dengan panjang ekor sperma, dalam hal ini luas kepala sperma yang kecil tidak menunjukkan ukuran ekor sperma yang lebih pendek, demikian pula sebaliknya luas kepala sperma yang besar tidak menunjukkan ekor sperma yang lebih panjang. Berdasarkan hasil pengukuran ini dapat diidentifikasi pula proporsi sperma $\mathrm{X}$ dan sperma $\mathrm{Y}$ dengan cara membandingkan ukuran luas kepala sperma setiap individu sel sperma dengan nilai rataan luas kepala sperma dalam populasi sperma tersebut.

Achdiat (2012) melaporkan bahwa pada Domba Lokal memiliki panjang 7,30 \pm $0,23 \mu \mathrm{m}$, lebar $4,25 \pm 0,13 \mu \mathrm{m}$ dan luas 31.01 $\pm 2.00 \mu^{2}$. Pada Domba Garut, telah dilaporkan memiliki rataan panjang kepala sperma $6.59 \mu \mathrm{m}(6-7 \mu \mathrm{m})$, dan lebar $3.99 \mu \mathrm{m}$ (3.5 - $4.5 \mu \mathrm{m})$ (Rizal et al., 2003), dan menurut Takdir et al. (2016) Domba Lokal memiliki panjang kepala $6.59 \pm 0.14$, lebar kepala $4.01 \pm 0.01$ dan luas kepala sperma $22.01 \pm 0.67$ $\mu \mathrm{m}^{2}$. Telah dilaporkan pula pada penelitian sebelumnya bahwa pada Domba Lokal memiliki panjang kepala sperma antara 8.14 $9.31 \mu \mathrm{m}$ dengan rataan $8.66 \mu \mathrm{m}$; lebar kepala sperma 4.50 - $5.39 \mu \mathrm{m}$ dengan rataan $4.93 \mu \mathrm{m}$; luas kepala sperma berkisar antara 22.97-59.30 $\mu \mathrm{m}^{2}$ dengan rataan $36.82 \mu \mathrm{m}^{2}$ (Solihati et al., 2017). Berdasarkan hasil-hasil penelitian peneliti sebelumnya maka dapat dikatakan bahwa ukuran-ukuran sperma Domba Lokal pada penelitian ini berada di kisaran ukuranukuran sperma yang dilaporkan peneliti lain.

Mohri et al. (1986) melaporkan bahwa berat dan ukuran kepala sperma X disebabkan adanya kandungan DNA di kepala sperma $\mathrm{X}$ sebanyak 3-4\% lebih besar dibanding DNA yang terdapat di kepala sperma Y. Sumner dan Robinson (1976) melaporkan bahwa kandungan DNA kepala sperma berkaitan dengan berat massa kepala. Ternak mamalia memiliki kromosom X lebih besar daripada $\mathrm{Y}$ sehingga mengandung lebih banyak DNA. Derajat perbedaan tergantung pada spesies. Pada sperma manusia rata-rata $2,9 \%$, sedangkan pada sapi rata-rata $3,8 \%$ dan pada chinchilla 7.5\% (Johnson, 1992). Goodall dan Roberts (1976) melaporkan bahwa sperma Y dengan ukuran yang lebih kecil dan mengandung lebih sedikit DNA, memiliki motilitas lebih tinggi dibanding sperma $\mathrm{X}$.

Berdasarkan hasil-hasil pengukuran sperma Domba Lokal pada penelitian ini, diketahui bahwa sperma Domba Lokal memiliki ukuran minimum dan maksimum. Ukuran-ukuran panjang, lebar, luas kepala sperma dan panjang ekor sperma Domba Lokal memiliki kisaran yang panjang, dengan panjang kepala minimum $6,852 \mu \mathrm{m}$ dan maksimum $10,172 \mu \mathrm{m}$; lebar kepala minimum $3,759 \mu \mathrm{m}$ dan maksimum $6,705 \mu \mathrm{m}$; luas kepala minimum 23,279 $\mu^{2}$ dan maksimum59,304 $\mu \mathrm{m}^{2}$; panjang ekor minimum $36,741 \mu \mathrm{m}$ dan maksimum 69,553 $\mu \mathrm{m}$. Berdasarkan hasil morfometri tersebut selanjutnya dapat diidentifikasi sperma pembawa kromosom $X$ dan, sperma pembawa kromosom X memiliki ukuranlebih besar dari rata-rata, sedangkan sperma pembawa kromosom Y memiliki ukuran yang lebih kecil dari rata-rata ukuran luaskepala sperma pada masing-masing domba, selanjutnya dapat dihitung proporsinya.

\section{Kesimpulan}

Disimpulkan bahwa hasil morfometrik sperma Domba Lokal dapat dijadikan dasar untuk sexing sperma pada Domba Lokal.

\section{Ucapan Terima Kasih}

Penelitian ini terlaksana atas bantuan hibah Penelitian Unggulan Perguruan Tinggi (PUPT) tahun anggaran 2017, untuk itu penulis mengucapkan terima kasih kepada Kementerian Riset dan Pendidikan Tinggi melalui Direktorat Riset dan Pengabdian Kepada Masyarakat dan Inovasi (DRPMI) Universitas Padjadjaran yang telah memberikan dana penelitian. 
Tabel 1. Rataan ukuran-ukuran sperma Domba Lokal berdasarkan Morfometrik

\begin{tabular}{ccccccccc}
\hline $\begin{array}{c}\text { No } \\
\text { Domba }\end{array}$ & \multicolumn{2}{c}{$\begin{array}{c}\text { Panjang_Kepala } \\
(\mu \mathrm{m})\end{array}$} & \multicolumn{2}{c}{$\begin{array}{c}\text { LebarKKepala } \\
(\mu \mathrm{m})\end{array}$} & \multicolumn{2}{c}{$\begin{array}{c}\text { Luas_Kepala } \\
\left(\mu \mathrm{m}^{2}\right)\end{array}$} & \multicolumn{2}{c}{$\begin{array}{c}\text { Panjang Ekor } \\
(\mu \mathrm{m})\end{array}$} \\
\cline { 2 - 9 } & Min & Max & Min & Max & Min & Max & Min & Max \\
\hline 1 & 6,852 & 9,243 & 3,759 & 5,131 & 23,279 & 40,783 & 36,741 & 60,450 \\
2 & 6,905 & 9,282 & 3,785 & 5,298 & 24,228 & 40,928 & 40,661 & 62,278 \\
3 & 6,992 & 9,284 & 4,045 & 5,298 & 25,039 & 40,997 & 42,684 & 62,867 \\
4 & 7,163 & 9,334 & 4,045 & 5,442 & 25,407 & 42,232 & 43,909 & 63,199 \\
5 & 7,166 & 9,339 & 4,057 & 5,518 & 26,281 & 42,762 & 45,837 & 63,640 \\
6 & 7,263 & 9,463 & 4,057 & 5,539 & 26,483 & 43,352 & 47,024 & 63,743 \\
7 & 7,392 & 9,463 & 4,092 & 5,570 & 27,070 & 43,357 & 47,767 & 63,880 \\
8 & 7,470 & 9,483 & 4,110 & 5,609 & 27,169 & 43,412 & 48,594 & 64,557 \\
9 & 7,474 & 9,483 & 4,203 & 5,639 & 27,425 & 43,863 & 48,809 & 65,821 \\
10 & 7,480 & 9,524 & 4,203 & 5,707 & 28,702 & 44,316 & 49,115 & 65,912 \\
11 & 7,493 & 9,690 & 4,232 & 5,712 & 29,069 & 44,657 & 49,588 & 66,653 \\
12 & 7,599 & 9,690 & 4,232 & 5,712 & 29,430 & 46,260 & 50,118 & 66,889 \\
13 & 7,700 & 9,702 & 4,322 & 5,720 & 29,612 & 46,469 & 50,628 & 66,964 \\
14 & 7,778 & 9,745 & 4,339 & 5,787 & 30,179 & 46,838 & 51,398 & 67,381 \\
15 & 7,803 & 9,888 & 4,367 & 5,808 & 30,380 & 48,924 & 51,523 & 67,440 \\
16 & 7,947 & 9,922 & 4,400 & 5,944 & 30,915 & 49,442 & 52,063 & 68,107 \\
17 & 7,969 & 9,949 & 4,400 & 6,254 & 31,389 & 50,322 & 52,249 & 68,335 \\
18 & 8,089 & 10,122 & 4,434 & 6,406 & 31,688 & 55,263 & 52,630 & 68,901 \\
19 & 8,152 & 10,130 & 4,535 & 6,615 & 31,837 & 56,491 & 53,159 & 68,956 \\
20 & 8,267 & 10,272 & 4,625 & 6,705 & 35,089 & 59,304 & 55,150 & 69,533 \\
\hline
\end{tabular}

\section{Daftar Pustaka}

Akhdiat, T. 2012. Proporsi Spermatozoa Y Hasil Pemisahan Dengan Fraksi Albumen Telur dan Lama Penyimpanan Semen Domba Lokal. Jurnal Ilmiah Ilmu-Ilmu PeternakanVol.XV(2).59-69.

Bintara, S. 2011. Rasio Spermatozoa X:Y dan Kualitas Sperma pada Kambing Kacang dan Peranakan Ettawa. Sains Peternakan Vol. 9 (2). 65-71.

Chaudhary I, M . Jain and A. Halder. 2014. Sperm Sex Ratio (X: Y Ratio) and its Variations. Austin Journal of Reproductive Medicine \& Infertility. Austin Publishing Group.

Garner DL, B.L. Gledhill, D. Pinkel, S. Lake, D. Stephenson, MA. Van Dilla, LA. Johnson. 1983. Quantification of the X- and Ychromosome-bearing spermatozoa of domestic animals by flow cytometry. Biol Reprod. 28(2). 312-21.

Goodall, H. and A.M. Roberts. 1976. Differences in motility of human X- and Y-bearing spermatozoa. Reprod. Fert. $48:$ 433-436.

Johnson, LA. 1992. Gender preselection in domestic animals using flow cytometrically sorted sperm. Journal of Animal Science 70 (Supplement 2) $8-18$.

Mohri H, S. Oshio, S. Kaneko, T. Kobayashi, R. Lizuka. 1986. Separation and characterization of mammalian $\mathrm{X}-$ and $\mathrm{Y}-$ bearing sperm. Development, growth and differentiation. 28 (1): $35-36$.

Rizal, M., M.R. Toelihere, T.L. Yusuf, B. Purwantara dan P. Situmorang. 2003. Karakteristik

penampilan reproduksi pejantan domba Garut. Jurnal Ilmu Ternak dan Veteriner. 8: 134-140.

Solihati, N., S.D. Rasad, R. Setiawan dan T. Kustini. 2015. Pengaruh Penambahan Glutation dan Alfa Tokoferol terhadap Daya Hidup Sperma Domba Lokal Umur Pubertas. Prosiding Seminar 


\section{Nasional Peternakan Berkelanjutan ke-7. Fakultas Peternakan Universitas Padjadjaran Bandung. 72-77.}

Solihati N., S.D. Rasad, R. Setiawan, and C. Alvionita. 2016a. Quality and Viability of Javanese Local Ram Semen at Different Age. Proceeding International on Livestock Production and Veterianry Technology. IAARD Press. 265-270.

Solihati, N., S.D. Rasad, R. Setiawan dan S. Nurjanah. 2016b. Post-Thawed Semen Quality of West Java Local Ram at Different Level of Glycerol. Proceeding of 3rd Animal Production International Seminar. UB Press. 414-416.

Solihati, N., S.D. Rasad, R. Setiawan. 2016c. Pengaruh Level Giserol Terhadap Keutuhan Membran dan Tudung Akrosom Sperma Domba Lokal. Prosiding Seminar Nasional Peternakan Berkelanjutan ke-8. Fakultas Peternakan Universitas Padjadjaran Bandung.
Solihati, N., S.D. Rasad, A. Yusrina. 2017. Evaluation the natural proportion of $\mathrm{X}-\mathrm{Y}$ chromosome bearing sperm of West Java Local Ram using morfometric methode. Proceeding $7^{\text {th }}$ International Seminar on Animal Production (ISTAP). Universitas Gadjah Mada, Yogyakarta.

Sumner, AT. and JA. Robinson. 1976. A difference in Dry Mass between the Head of X-andY- Bearing Human Spermatozoa. J. Reprod Fert., 8 : 9 14.

Susilawati, T. 2014. Sexing spermatozoa. Hasil penelitian laboratorium dan aplikasi pada sapi dan kambing. Universitas Brawijaya (UB) Press. Malang.

Takdir, M., Ismaya, S. Bintara dan M. Syarif. 2016. Proporsi X dan Y, Viabilitas dan Motilitas Spermatozoa Domba Sesudah Pemisahan dengan Albumin Putih Telur. Prosiding Seminar Nasional Inovasi Teknologi Pertanian.1333-1340. 